
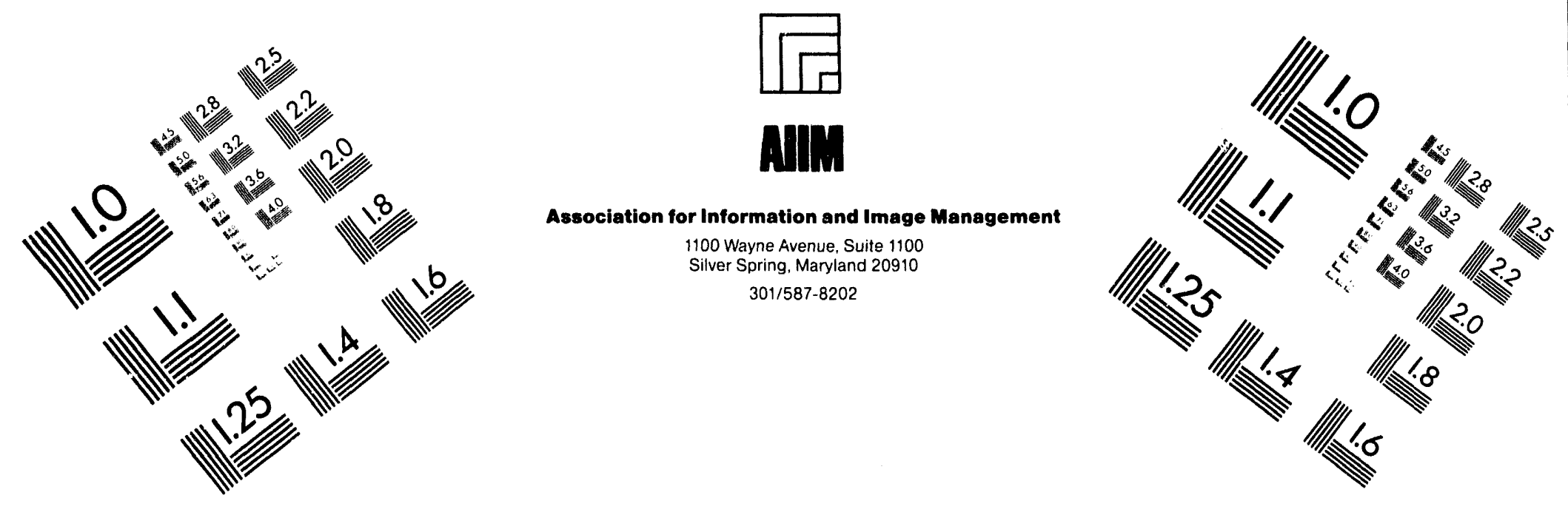

\title{
Centimeter
}

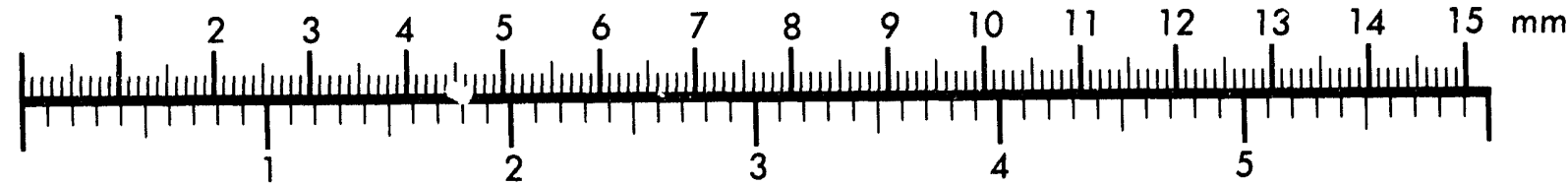

Inches
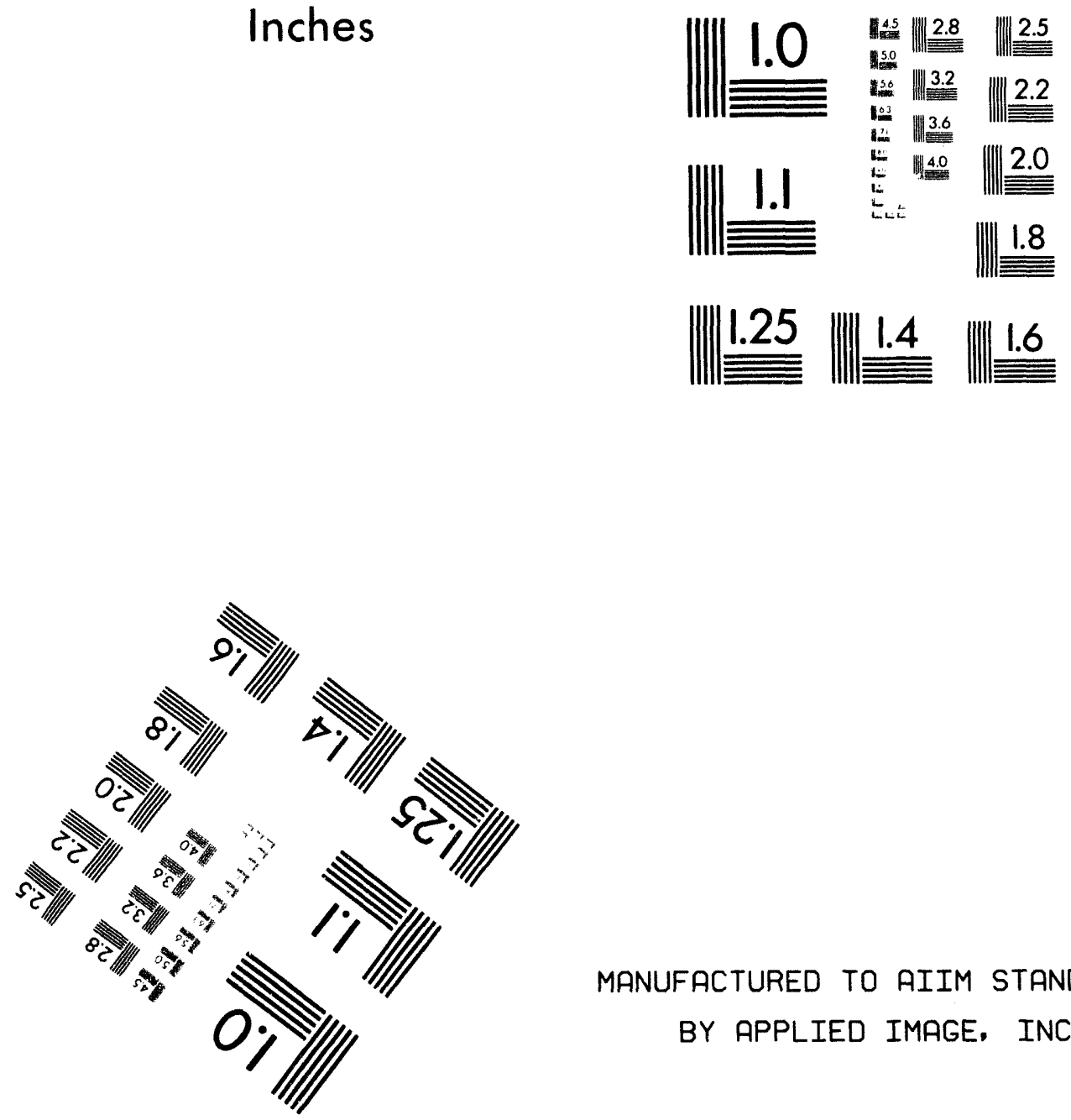

MANUFACTURED TO AIIM STANDARDS

BY APPLIED IMAGE, INC.

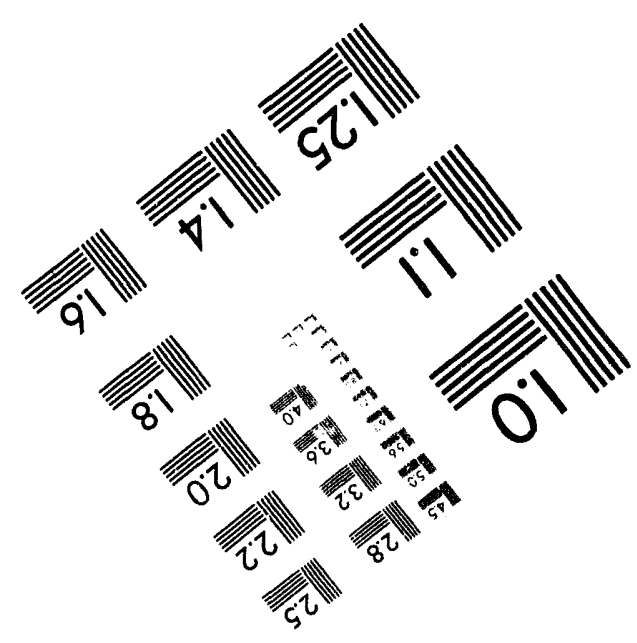



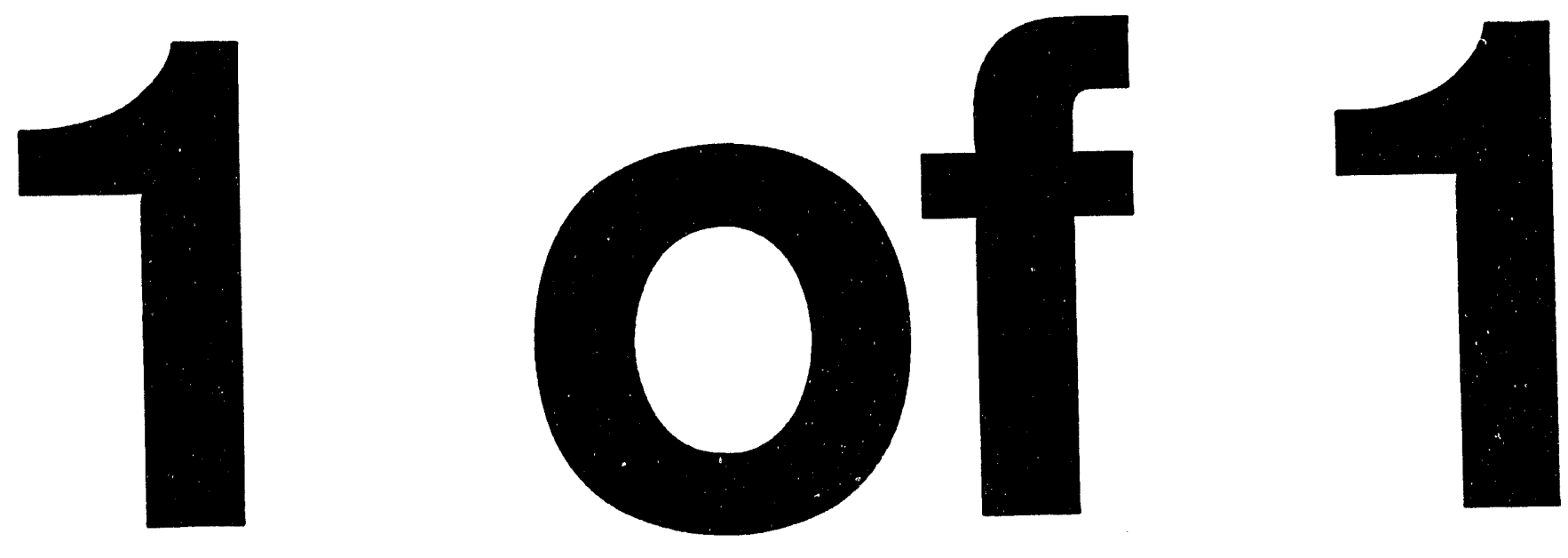


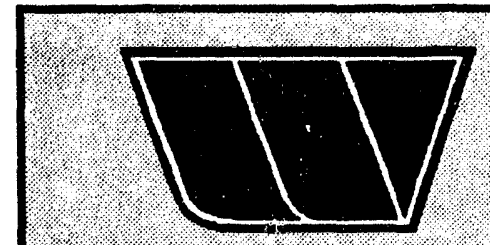

Westem Covemor's Assoctation
Federal Advisory Committee To Develop On-Site Innovative Technologies

\section{ABANDONED Mine WASTE WORKING GROUP REPORT}

December 10, 1993
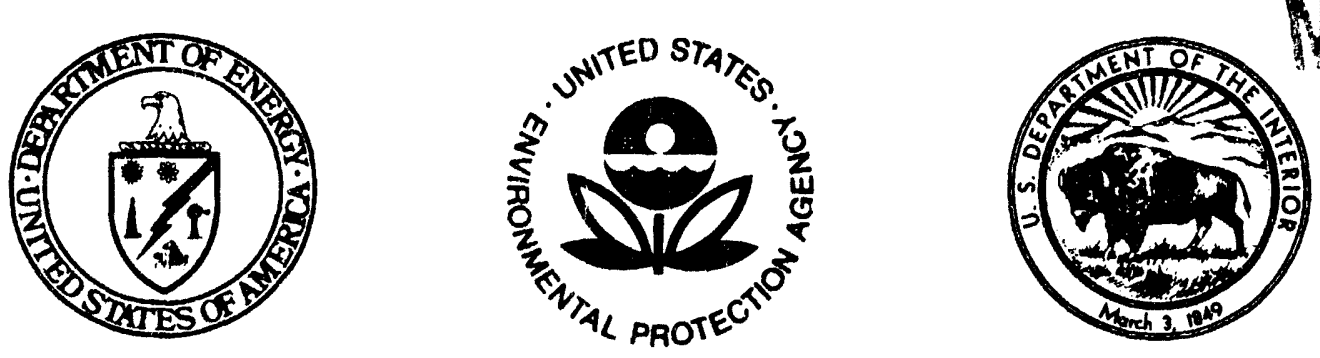

MSTR 


\section{Table of Contents}

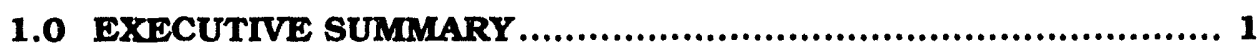

1.1 FINDINGS OF MINE WASTE WORKING GROUP ............. 1

1.2 OPPORTUNITIES TO SOLVE PROBLEMS ..................... 2

2.0 STAKEHOLDERS ADDRESS THE PROBLEMS ...................... 3

3.0 THE MINE WASTE PROGRAM .................................... 3

3.1 Unique Challenges to Mine Waste Remediation ............... 4

3.2 Mine Waste Hazards .......................................... 4

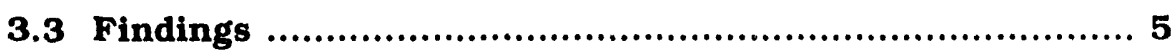

4.0 CURRENT TECHNOLOGY DEVELOPMENT PROGRAMS ...........6

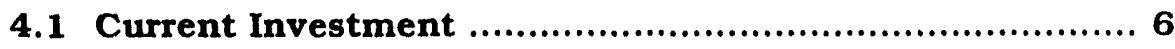

4.2 Strengths and Weaknesses of Existing Programs ............ 7

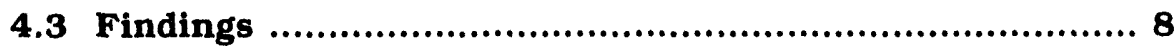

5.0 PROBLEMS AND ISSUES THAT NEED TO BE ADDRESSED ...... 8

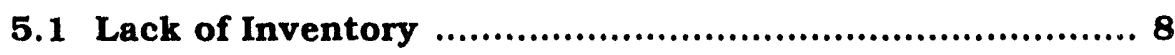

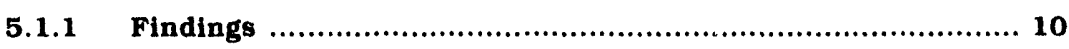

5.2 Regulatory and Institutional Barriers ...................... 10

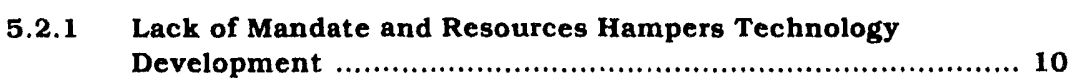

5.2.2 Regulatory Constraints .......................................... 11

5.3 Need to Improve Stakeholder Participation ................ 13

5.3.1 Stakeholder Participation in Demonstration Projects ............ 14

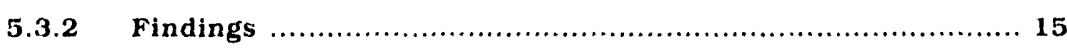

5.4 Improve Support for Commercialization .................. 15 


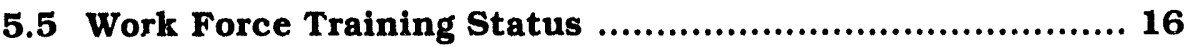

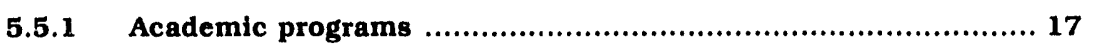

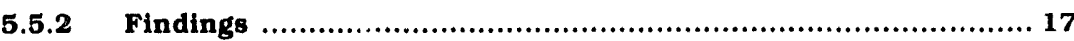

6.0 DEMONSTRATION PROJECTS TO TEST SOLUTIONS .............. 17

6.1 Process used to identify potential projects.................. 18

6.2 How Projects were Evaluated .................................. 18

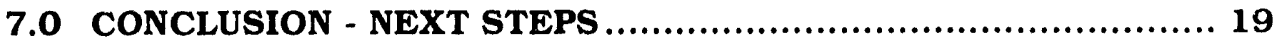

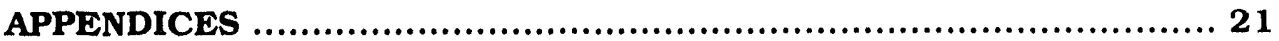

Appendix A - Working Group List

Appendix B - Project Questionnaire Form

Appendix C - Mine Waste Projects

Appendix D - Project Criteria

Appendix E - Potential Mine Waste Candidate Demonstration Projects 


\subsection{EXECUTIVE SUMMARY}

The Mine Waste Working Group discussed the nature and possible contributions to the solution of this class of waste problem at length. There was a consensus that the mine waste problem presented some fundamental differences from the other classes of waste addresses by other DOIT working groups. The principal conclusions of the Group are presented below.

\subsection{FINDINGS OF MINE WASTE WORKING GROUP}

\section{Inventory of Abandoned Mine Waste Sites Needed}

Mine waste problems on or affecting federal lands pose significant hazards to human health ard safety and to the environment. However, there is no comprehensive inventory of comparable and reliable information on the location of mine waste sites throughout the nation and the nature of the hazards and contaminants at those sites. Without this information it is impossible to prioritize cleanup and develop meaningful marketing information for technology vendors. Existing and emerging efforts at the state and federal level to inventory the location and nature of sites are not coordinated, sometimes duplicative, and may be collecting different data.

Lack of National Mine Waste Remediation Program Slows Technology Progress

The public and private investment in the development of new technologies for mine waste remediation is substantial and probably adequate under the current situation where there is no national commitment to remediate mine sites. However, new and existing terhnologies will not be widely deployed, evaluated, and commercialized without the development of a public or private funding source of a ilational magnitude for mine waste remediation.

\section{Regulatory Barriers Impede Technology Development}

Even with the developnent of a funding source for mine waste remediation, regulatory obstacles and the inflexibility of cleanup and water quality standards will continue to impede the testing and evaluation of innovative technologies and remediation of mine waste sites.

\section{Improved Stakeholder Participation Needs to be Tested}

Stakeholder participation in technology demonstrations is just as important as in site cleanups however no model has been developed or tested to determine how stakeholders should best be involved in site and technology selection leading to eventual demonstrations and cleanup. 
Acquiring and Sharing Information is Critical to Commercialization

Once funding and regulatory barriers are overcome, reliable information on the cost and performance of technologies, and an accepted mechanism for sharing that information, serve as final barriers to commercialization. The use of private, working mine sites, test beds. or well characterized sites to test and evaluate innovative technolo gies could help in accelerating the testing process and developing reliable information.

\section{Work Force Training is Currently Satisfactory}

Existing college-level work force training programs are adequate to meet the existing needs for innovative mine waste technology development and deployment. If significant mine waste remediation is undertaken in the near future, the adequacy of the training programs will need to be re-evaluated.

Identification of Sites or Technologies for Demonstration Projects is Premature

Because of the unique nature of mine wastes and the need to address the issues identified above, a site/technology demonstration program of the type proposed by other Working Groups is premature. The Mine Waste Work Group is prepared to solicit information for projects that would be developed from the ground up. These projects will build on the lessons learned and will address technology needs for key cleanup concerns, test new regulatory and stakeholder approaches, and work to improve commercialization at mine waste sites.

\subsection{OPPORTUNITIES TO SOLVE PROBLEMS}

New approaches to address some of these needs might be tested in conjunction with ongoing State/Federal activities. The Mine Waste Working Group has identified several examples of the types of projects that could be used. The title and brief description of live such projects have been categorized according to the way such projects might relate to the key findings.

- Regulatory barriers - Triumph Mine (alternative to Superfund listing for remediation), Pennsylvania Mine (liability and water quality standards)

- Stakeholder participation - Midnite Mine (stakeholder involvement in technology testing and remedy selection), Sheldon Mine-Prescott Mining Project (stakeholder involvement in technology and remedy selection)

- Commercialization - Lily Orphan Boy Mine (Cost and performance information/multi-state permit review for bacteria for metals in mine drainage) 
Additionally, the US Bureau of Mines, acting for the Department of the Interior, has offered to fund a project to bring together interested stakeholders to develop an inventory model that can be used to ensure the utility of the inventory process and assist in the process of helping achieve the ultimate compatibility among the various inventory initiatives. In preliminary steps to initiate this project, discussions on this issue have begun among Western Govrnors' Association, Bureau of Mines, and state and federal agency represenatives.

\subsection{STAKEHOLDERS ADDRESS THE PROBLEMS}

The Mine Waste Working Group is comprised of a broad set of stakeholders from various interests (see Appendix A for membership roster). The Mine Group met four times between May and October, 1993 to develop the information requested by the DOIT Committee.

At its first meeting the Group identified key areas of concern and began to revise the Ad Hoc Working Group's criteria for identifying possible demonstration projects at which to test new ideas. With the permission of the DOIT Committee Selection Subcommittee, the Group added new members to broaden stakeholder representation for its second meeting at which criteria were finalized. At the third meeting, the group was briefed on several mine waste demonstration projects and opportunities and the group focused on how to appropriately identify potential demonstration projects. At its final meeting the group reviewed information generated by a request for information which was distributed by the group and identified several potential approaches which could be used to test new alternatives for deploying and eventually commercializing innovative technologies.

What follows is the Mine Waste Working Group's report to the DOIT Committee. The Group stands ready to follow up on any of the recommendations of the DOIT Committee.

\subsection{THE MINE WASTE PROGRAM}

Abandoned and inactive mines pose a significant threat to the environment and human health and safety. As such, mine sites on or affecting federal lands represent a tremendous liability to the 
federal government. Mine wastes present unique problems. This is due to the shear volume of the waste, acreage involved, miles of stream affected, type of contamination, and presence of open shafts and unstable structures. In many instances, depending on site specific circumstances, abandoned mine wastes pose little environmental threats. Waste piles at various sites may look identical, however chemical conditions may be entirely different. Each mining waste site must be evaluated individually to determine the magnitude of the problem.

\subsection{Unique Challenges to Mine Waste Remediation}

The mine waste problem is different from the wastes dealt with by the other DOIT working groups. Mine wastes have six characteristics that pose unique challenges for remediation. First. the volumes of waste involved, the diversity of the types of problems, and the geographic dispersions of the sites. Second, the number of individual sites is very large - estimated to be over a half million. (EPA Region VIII estimates that between 800 and 1,500 mine waste sites may need to be assessed in terms of environmental and human health threats.) Third, many sites are relatively inaccessible during all or part of the year and often lack infrastructure. Fourth, there is an undefined potential to recover valuable commodities during cleanup (gold, silver, and other heavy metals). Fifth, mine waste sites often involve mixed patterns of ownership (state, federal, private) and have complicated liability issues. Sixth, the potential exists for continuous long-term release of naturally occurring contaminants. For example, natural processes and reactions are intensified by acid mine drainage and lead to the release of higher levels of contaminants than are naturally contained within the waste rock.

\subsection{Mine Waste Hazards}

Environmental and human exposure to contamination (an be through solid (relic tailings/waste piles) or liquid media (surface water/groundwater). Typical mine wastes generate contamination composed of certain heavy metals, acidity, cations/anions, and sometimes nutrients and cyanide. Often it is the heavy metals emanating from waste piles that are most harmful to the receiving environment. Toxic effects to people and the environment can be caused by short term or long term exposure and can depend on the concentration of contaminants, length of exposure, and distance between contaminant sources and the environmental/human receptors. Additional public health and safety risks include physical hazards such as open shafts and adits, dilapidated structures, unstable slopes, and abandoned explosives and processing chemicals.

The composition of contamination resulting from the waste is related to the method of ore recovery used at a given operation (extraction, 
beneficiation, or processing). Extraction of ore generates waste rock and low grade stockpiles which can also be discrete sources of contamination. Beneficiation procedures (gravity separation, amalgamation, flotation, leaching, autoclaving, etc.) which are used to concentrate a desired mineral and ore refining methods (roasting and smelting) which produce the actual metal all have unique waste stream characteristics. Depending on the method in which the waste was generated and treated and on the geologic makeup of the material, the type of contamination can vary significantly among sites. In addition, the excavations left behind can also cause siltation and other contamination problems.

The environmental impact of mine waste contaminants (see table, next page) is ofter exacerbated by the oxidation of sulfide minerals and the resulting acid mine drainage. The acidity dissolves metals and increases metal concentrations in waters. These waste streams offer significant potential for the collection, commercialization, and reuse of waste chemicals.

The following chemical constituents and characteristics may be found in wastes associated with abandoned mines and in drainage (to both surface and groundwater) from those sites:

\begin{tabular}{|l|l}
\hline Heavy Metals & Nutrients \\
Aluminum & Nitrate \\
Aresenic & Nitrite \\
Cadmium & Ammonia \\
Chromium & \\
Cobalt & \\
Copper & \\
Iron & \\
Lead & \\
Manganese & \\
Mercury & \\
Molybdenum & \\
Nickel & \\
Radium & \\
Selenium & \\
Silver & \\
Uranium & \\
Vanadium & \\
Zinc & \\
\hline
\end{tabular}

\section{Cations/Anions}

Calcium Magnesium Potassium Sodium Bicarbonate Carbonate Chloride Sulfate

\section{Other}

Acidity

Dissolved Solids

Suspended Solids

Conductivity

Hardness

Turbidity

Alalinity

Cyanide

Cyanide Complexes

\subsection{Findings}

Mine waste problems on federal lands pose significant hazards to human health and safety and to the environment. The characteristics of mine waste pose challenges for technology demonstration and remediation. 


\subsection{CURRENT TECHNOLOGY DEVELOPMENT PROGRAMS}

\subsection{Current Investment}

Several different federal agencies have ongoing technology development and implementation efforts related to mining waste. In addition, some states and private industry sectors expend resources in technology development to address problems caused by mine waste contaminants. Table 2 below summarizes estimates of resources currently directed to support of mine waste remediation technology.

\begin{tabular}{|c|c|}
\hline Organization & Funding ( $\$$ million/year) \\
\hline U.S. Bureau of Mines & \\
\hline Environmental Technology & $\$ 20$ \\
\hline Generic Ctr/Min Institutes & $\$ 3$ \\
\hline USEPA & \\
\hline Mine Waste Pilot Program & 1 \\
\hline Non-Point Source & 1 (Est) \\
\hline Superfund & 1 (Est) \\
\hline DOE & \\
\hline Resource Recovery & 2 \\
\hline USFS & $?$ \\
\hline DOD & $?$ \\
\hline States & $1-5$ (Est) \\
\hline Mining Industry & $1-?$ (Est) \\
\hline Other & $?$ \\
\hline TOTAL & $\$ 24+4 \cdot 7^{+}($Est $)=28-31^{+}$ \\
\hline
\end{tabular}

As the table indicates, certain data on expenditures are not known. There are no comprehensive estimates available from the mining industry detailing industry investment in remedial technology development. It is recognized this investment may be dedicated to specific sites and further that this sector may retain proprietary interests which must be respected.

The Group feels new and enhanced data collection efforts should be undertaken to help provide a clearer picture of the nation's mine waste technology effort and could be integrated into a technology database or clearinghouse. A survey of American Mining Congress members could yield new information. Other data that were not immediately available were exact figures on EPA's non- 
point source program and state expenditures for mine waste technology development and deployment. The Group has expressed an interest in acquiring this information in order to better identify sites in subsequent years.

The different federal programs address different parts of the RD\&D spectrum. For example, most of the Bureau of Mines work is a structured technology development program while most of EPA's Mine Waste Pilot program is focused on technology demonstration.

The conclusion based upon the available information is that there currently is a significant investment to develop and demonstrate mine waste remediation tecinnology.

\subsection{Strengths and Weaknesses of Existing Programs}

There are strengths and weaknesses in the current effort to develop and deploy mine waste technologies. The funding issue for mine waste cleanup remains paramount because without funding there is weak demand for new technologies. Fortunately, Congress is currently debating a program and funding options to begin addressing mine waste cleanup. In addition, the mineral bearing nature of the wastes offers a prospect, in some situations, of being able to generate revenues to partially offset the costs of remediation through remining/metal recovery. Finally, the availability of human resources to develop and deploy mine waste remedial technologies is judged to be at least adequate. There is a pool of trained researchers and an abundance of other skills.

On the other side of the issue, there are a number of things which could be improved. Perhaps first and foremost is the need for recognition that this remediation effort will be a long term activity and the temptation of seeking quick fixes should be avoided. The nature of the problem is such that it may take decades to be sure that a particular technology can be depended upon to "solve" a problem. Further, while treatment technologies that allow one to "walk away" from the site would be the optimum situation, the reality is that for some classes of problems, the most economical solution might well be perpetual treatment to prevent contaminants from reaching the receptor of concern. Even, "walk away" solutions will require some operation and maintenance.

In a related vein, while short term (e.g., year long) demonstration are of some value, an assessment protocol needs to be developed that allows results to be put into a context that allows valid comparison and assessment. In many cases, this will require expensive and time consuming site assessment so that all of the ramifications of a technology can be understood. For example, a promising technology for removal of metals contamination from mine effluents involves the use of biologically generated $\mathrm{H}_{2} \mathrm{~S}$ to reduce soluble metal species to rela- 
tively insoluble sulfides. While this helps solve the immediate problem, the long term fate of these sulfides also needs to be considered.

In addition to the need for assessment protocols, there is also a need for development of acceptable risk assessment techniques to allow prioritization of sites to be remediated. This also relates to the need for a properly ccinstructed inventory of sites (see discussion below). Finally, technologists seeking to target their developments (and those assessing the commercial potential of the remediation market) need certain types of data that are far different than mere geographic location.

To be effective, a technology development effort for mine waste needs continuity and critical mass. The proliferation of small "research institutes" should be discouraged in favor of a structured program built on an experienced research infrastructure.

\subsection{Findings}

The public and private investment in the development of new technologies for mine waste remediation is substantial and probably adequate under the current situation where there is no national commitment to remediate mine sites.

Acceptable risk assessment methods must be developed to prioritize problem sites.

The development of long term solutions should be encouraged.

\subsection{PROBLEMS AND ISSUES THAT NEED TO BE ADDRESSED}

Discussed below are problems and issues that have been identified by the Abandoned Mine Waste Working Group. These concerns need to be addressed to improve technology development and commercialization. Some can be addressed through demonstration projects. Others require congressional mandate or modificiation of regulations.

\subsection{Lack of Inventory}

One of the topics that the Mine Waste Working Group felt particularly important to call out for separate discussion is the need for a proper inventory of abandoned mine sites. Completion of a prop- 
erly constructed and understood inventory is critical to the accomplishment of the goals of the DOIT mine waste effort.

A proper inventory serves a number of purposes. One is the commercialization of technology. Absent an identification of the number of sites, the nature of the sites, and a measure of their priority, private industry is faced with an intimidating and perhaps unreasonable challenge with regard to allocation of its resources. This point was explicitly cited at the DOIT Commercialization Roundtable, and it is perhaps nowhere more true than in the mine waste area because of the diverse nature of the mine waste problem.

A comprehensive inventory of inactive and abandoned mines ic needed on the national level if aitention is to be focused on priority sites. Currently, there is no basis for prioritizing sites in a consistent manner to identify sites that exhibit the greatest need for remediation. Such documentation is crucial if we are to spend remediation dollars wisely.

In addition, absent a suitable inventory, there will never be a clear indication of the magnitude of the resources required to deal with mine waste problems nor a suitable yardstick by which to measure progress. The cleanup costs of mine waste problems are certainly in the hundreds of millions and perhaps in the tens of billions of dollars. Since there is no viable private party to assume responsibility for cleanup in most cases, the burden will fall on local, state, and federal governments. Site remediation must be weighed against other priorities, revenue sources identified, and available funds. Without a suitable inventory, prioritization of resource allocation to achieve maximum efficient yield is virtually impossible.

Furthermore, as discussed at length by the Mine Group, without an inventory that allows categorization of sites by types of problems, the development of targets for innovative technology will always be subject to divisive debate on the value and appropriateness of the technical approaches. What is a "representative site" for acid drainage treatment? Are the worst contributors to water pollution point or non-point sources? Should we focus on groundwater contamination or treatment of surface flows?

The Federal land management agencies are just beginning to mount a comprehensive effort to identify their mine waste problems. A number of states have been conducting inventories for years while others have either not begun or are just beginning. The cost of constructing an inventory can cost hundreds of thousands of dollars at the state level and millions at the Federal level. Unfortunately, there has been no general discussion, hence there is no agreement, on what data collection methodologies should be used or what data an inventory should contain. Existing inventories, in many cases, cannot be compared much less consolidated because of the different approaches used for data collection. Moreover, none of the inventories appear to have a clear focus on the ultimate use of the inventory data, (e.g., prioritization of problems, allocation of resources, targets 
for technology development, etc.) The impetus associated with the proposed revisions to the Mining Law of 1872, public and Congressional attention directed at hazardous conditions on public lands, proposed changes to solid waste and water protection legislation, and other factors could worsen the problem. Unless there is a dialogue among the parties involved in the process, they will probably find themselves in the position of having to stop and redo much of the work at major cost, both financial and in terms of credibility.

The US Bureau of Mines, acting for the Department of the Interior. has offered to fund a suitably structured effort to bring together the interested parties to initiate the dialog on the goals of an effective inventory effort. For example, should the site locations be keyed to watershed, ecosystem, or other impact areas. It has further suggested that the WGA provide assistance and help in bringing the nonFederal stakeholders into the process to help assure that no reasonable needs are overlooked. The objective of this process is to build on the lessons learned from past efforts and the interests of citizens, industry, regulators, technologists, and other interested entities to establish an agreed-upon model that those involved in the inventory process can use to guide their efforts. The Mine Waste Working Group supports the concept of the proposal.

\subsubsection{Findings}

There is no comprehensive source of comparable and reliable information on the location of mine waste sites throughout the nation and the nature of the hazards and contaminants at those sites.

Existing and emerging efforts at the state and federal level to inventory the location and nature of sites are not coordinated, sometimes duplicative, and may be collecting different data.

\subsection{Regulatory and Institutional Barriers}

Regulatory and institutional barriers pose difficulties for not only the demonstration of innovative mine waste remedial technologies, but for application of conventional technologies in cleanup of mine waste problems.

\subsubsection{Lack of Mandate and Resources Hampers Technology Development}

The absence of clear statutory mandates and dedicated funding has significantly hampered initiation of coordinated cleanup efforts in the United States. Although no national inventory of hardrock mine waste sites has been conducted, one-half million sites or more are believed to exist across the nation. Problem accountability is a serious issue at most of these sites. Many of these problems originated in the 1800s. Current site owners often have limited linkage to those who caused the problems and little, if any, financial capabilities to correct them. 
Only about 50 of the most serious mine sites are listed for cleanup under Superfund (CERCLA authorities), the predominant national program for cleaning up major environmental problem areas. Even then, the use of Superfund authorities for remediation of mine waste problems is resulting in lengthy cleanup periods due generally to the litigious and highly prescriptive remedial process under CERCLA, the complex technical nature of mine waste problem sites, and the magnitude of waste volumes.

Other than the limited use of the funds under the national abandoned coal mine land program (SMCRA) which coal producing states can tap after finishing remediation of coal sites, no other national remedial program for hardrock mine wastes exists. The costs of the overall cleanup have been estimated to be as high as the tens of billions of dollars. States generally lack this level of resources although some are pursuing limited cleanup under related activities such as a state Superfund program in Montana and nonpoint source program funds under the federal Clean Water Act. However, the use of regulatory approaches independent of the funding of a national remedial program cannot solve the problem.

Congress is currently considering the creation of dedicated funding for abandoned hardrock mine waste cleanup in conjunction with reauthorization of the 1872 Mining Act. Although such funds could provide significant help, those amendments are not likely to address a series of institutional and procedural issues critical to the effective use of those funds for public health, safety, and the environment (i.e., cooperative federal/state/local efforts, integration with ongoing regulatory programs, focus on priority problem areas). Such institutional and procedural arrangements might best be accomplished through the collective efforts of diverse stakeholders at the federal, state, tribal, and local levels similar to those involved in the Mine Waste Working Group. The creation of a national program would also help increase the opportunity for the deployment and commercialization of remedial technologies and establish an enhanced basis for defining future innovative technology needs.

\subsubsection{Regulatory Constraints}

There is consensus within the mine waste community that current state and federal regulatory structures do not provide incentives for the remediation of mine waste problems. The degree to which the current structure provides disincentives is a matter of uncertainty. The perceptions of the various parties is influenced by their experiences, perspectives (citizen group representative, regulator, mining company, technologist, etc.), and the particular site(s) they have in mind.

CERCLA. Much, for example, has been said about the chilling effect of Superfund on cleanup from the standpoint of potential future liability. While it is true that the joint and several nature of 
Superfund liability could, potentially, subject those involved in mine site cleanup to a future liability arising from their efforts to remediate a site, the issue is not black and white. First of all, the question of potential Superfund liability is limited to those sites that are, or have the potential to be listed sites. This is likely to be a small subset of the universe of mine sites - sites that, under the provisions of the Hazard Ranking System, are identified as posing the most severe threats to the environment or human health. However, the new HRS places greater emphasis on environmental impacts potentially resulting in a larger number of mine site Superfund listings than under the previous system.

Second, sites that are subject to the provisions of Superfund are also subject to the good samaritan provisions of Superfund - essentially a shield that protects those involved in approved remediation activities. The argument could be made that these provisions. coupled with the flexibility EPA has in dealing with other regulatory regimes on Superfund sites and the low probability that EPA or the courts would, as a matter of equity, pursue or support the prosecution of parties trying to help correct a problem, actually negates the Superfund liability issue as a practical matter. However, the perception that Superfund liability is an obstacle remains as a disincentive. The theoretical strict application of joint and several liability to a demonstration sponsor still forces the sponsor to determine if they are willing to live with the risk in an often times unpredictable regulatory environment.

Water Guality Regulations. Although compliance with RCRA and air pollution regulations are usually not a problem (particularly with the current RCRA exemptions for mining), water quality regulatory requirements can be more problematic. Where remedial actions result in a point source discharge, such discharge must meet the NPDES permit conditions including compliance with prevailing state/ federal water quality stream standards of the receiving waters. This can be difficult to attain in streams located in mineralized areas, common to mine waste sites, particularly where these stream standards are based upon national water quality criteria (laboratory results) for dissolved metals. In some cases, the numerical levels of such standards may be lower (more stringent) than the natural back ground levels in those streams or more protective than needed for the native aquatic life which may have acclimated to higher natural levels of metals. For example, naturally reproducing fishable populations of trout have been found in reaches of the South Fork Coeur d'Alene River where dissoived zinc concentrations are 97 micrograms per liter. The Gold Book standards for support of freshwater biota adjusted for hardness are 27 and 29 micrograms per liter respectively for chronic and acute exposure.

Possible Solutions to Regulatory Constraints. A number of alternatives have been proposed that deal with aspects of the problem. One common theme is to amend the existing statutes to create various exceptions for mine waste reclamation activities, e.g., to create a "remining" exemption to CERCLA or the Clean Water Act. History 
would suggest that reforming the regulatory fabric in this manner may create more problems than it solves. An example of this from the coal mining area is the problems caused to SMCRA by the " 2 acre exemption" which was finally taken out of the Act by Congress.

An alternative approach might be to encompass the reclamation of non-Superfund sites in a comprehensive piece of legislation specific to this problem - revisions to the Mining Law of 1872 or other appropriate legislation. This approach might, for example, allow the regulatory authority to maintain oversight of the use of funds for reclamation of truly abandoned sites to effect watershed wide improvements instead of forcing site by site adherence to water standards. Such an approach might also include provisions such that regulatory and land management agency approval of voluntary cleanups would hold the performing entity to attainment of state of the art cleanup standards but relieve that entity of subsequent liability, such as those related in subsequently changed standards.

Where a remedial activity at a site has been found to comply with all appropriate regulations, the current regulatory structure does not accommodate the transfer of this regulatory approval to another site or another state. Regulatory requirements tend to differ somewhat from state to state. Although state environmental regulations must comply with minimum federal provisions in order to gain delegation of a federal program, they often differ from the federal regulatory template for that program in order to meet particular needs of that state. Even within a state, regulatory requirements for air and water emissions can vary from site to site depending upon the quality and use of the impacted surface and ground waters and ambient air protection.

\subsection{Need to Improve Stakeholder Participation}

The Mine Waste Working Group advocates stakeholder participation in the permitting, deployment, and evaluation of innovative technologies for mine waste. Mining wastes are often located in remote terrain away from large population areas. This can pose unique challenges for involving stakeholders in demonstrations of technologies. The Mine Waste Working Group also recognizes that there is probably a difference between stakeholder participation which focuses on the testing of technologies and the level of involvement related to site cleanup.

The USEPA conducted an extensive series of meetings under the auspices of the Federal Facilities Dialogue during this last year to identify guidelines for stakeholder involvement in the cleanup of federal facilities. The Dialogue focused primarily on DOE and DoD types of cleanups but there may be some transferable lessons from the guidelines which are applicable to mining wastes. 


\subsubsection{Stakeholder Participation in Demonstration Projects}

A subgroup of the Mine Waste Working Group identified the main tasks, and some of the options for accomplishing successful stakeholder participation. The major tasks identified were:

(1) identification of stakeholders; and

(2) providing a framework for meaningful stakeholder participation during all phases of the project;

Identification of Stakeholders. At a demonstration site the primary task is to identify the stakeholders. Included should be anyone interested in general restoration of the site, or in advancement of the technology. Stakeholders might include:

regulators

citizen groups

environmental groups

business organizations

venture capitalists

tribal members land use managers

local officials

land owners

technology developers

mining industry

Techniques for identification might include:

local press releases and ads

public mailings

direct contact with local leaders and organizations

public meetings to explain the project

Providing a Framework for Meaningful Stakeholder Participation. A model needs to be developed in order to provide a framework for each project, but a great deal of flexibility needs to be built into this model in order to allow for local needs and circumstances, and to encourage innovation at the project level. Ultimately, the identified stakeholders need a forum to understand the intent and scope of the project, and provide meaningful input. Representatives could hold a seat on the Project Development Team, or form a local advisory committee.

Some of the characteristics of a framework are:

- representative involvement (i.e. each stakeholder group would be represented at the table)

- clearly defined groundrules with responsibilities and authorities for both the stakeholder representatives, and the group itself, clearly defined 
- timely access to project information for stakeholders

- $\quad$ stakeholder group has a formal means of expressing its opinions to the responsible authority but final decision making authority will probably rest with the entity responsible for managing the project

- formal opinions of the stakeholder group should be arrived at by consensus

- $\quad$ stakeholder representatives must attend meetings

- an administrative record which reflects how issues are considered and addressed

- the membership of the stakeholder group should be determined by the framework, but must remain flexible because additional stakeholders may be identified after the group has been formed

- Special consideration should be given to tribes in instances where environmental problems impact tribal lands

\subsubsection{Findings}

There is currently no consensus on, or a model for, stakeholder participation at mine waste demonstration projects and cleanups.

A roundtable on stakeholder participation, like those convened by the DOIT Committee on Commercialization and on Regulatory Barriers, could provide a forum for developing a model to test at demonstration projects sponsored by the DOIT Committee. All four working groups could benefit from a discussion of questions such as:

- Should there be a different model for stakeholder involvement for technology demonstrations vs site cleanup?

- Does a different model apply to different waste streams depending upon risk?

\subsection{Improve Support for Commercialization}

Mine waste problem sites are typically found in rural areas, often economically depressed regions with few active economic development opportunities. A DOIT program at these sites could improve local economic activity and could have long term benefits for employment and resource management if full scale restoration follows successful demonstration work.

In the context of mine waste technologies, the terms "commercialization" and "technology transfer" are to some degree interchangeable. The difference between the two terms is that technology transfer is associated with the activities of moving a technology 
out of the laboratory phase while commercialization implies marketability and marketing activities.

There are several obstacles to the commercialization of new technologies for mining waste including lack of funding for mine waste cleanup, lack of information on the size and location of the market for technologies (see inventory discussion above), the profit margin for mining waste technologies, and an inadequate information network about new technologies and their cost and performance.

The Group discussed different ways to improve the commercialization of mining technologies. One idea was to establish a better information network and/or clearinghouse(s) to validate and disseminate information on new technologies. Another idea was to use working mines as demonstration sites for new technologies. The advantage of using working mines is that they already have all the necessary infrastructure in place. In addition, there may be additional advantage if the working mine is a non-federal site because of cumbersome agency rules and regulations which could slow down a technology demonstration. Among the disadvantages of the use of a working mine is the fact that the differences in the infrastructure, the nature of the wastes, and the problem itself may make the lessons learned irrelevant to the solution to the abandoned mine waste problem.

A variation on the working mine approach would be to establish "test beds" for mine waste technologies. This would be especially useful in developing innovative characterization technologies. A test bed would facilitate more rapid testing and evaluation of technologies because the regulatory process would be well established. In addition, test beds could help build and disseminate reliable information on technology performance and serve as a clearinghouse for technology information. EPA and DOE have established a test bed at the Berkeley Pit in Butte, Montana. Disadvantages of this approach are that the diversity of abandoned mine waste problems makes it unlikely that any single or limited number of test beds could realistically represent the range and nature of the problems.

\subsection{Work Force Training Status}

An informal survey of industry and academic representatives in $\mathrm{Ne}$ vada, Colorado, Montana, Idaho, New Mexico, and South Dakota was conducted to collect perspectives on the current effort on workforce training efforts for mine waste technology development, deployment. and site cleanup. Areas of inquiry were: 1) what was being offered by the various colleges and universities related to mine waste remediation and 2) what were the perceptions of industry relative to meeting professionals training needs both now and for the future.

Industry concerns focused on insuring that any program in mine waste remediation involve a strong foundation in math. physics, and chemistry. The basic program should have a strong focus and orien- 
tation on engineering, hydrology, biology, etc. Support studies should be encouraged in the areas of geology, hydrologic geochemistry, toxicology, biology, mining engineering, environmental law/ regulations in order to encourage cross-discipline training.

\subsubsection{Academic programs}

The survey showed that most schools offer traditional curriculum and degrees such as engineering, geology, biology, and chemistry. Also, most schools offer special elective courses in mine waste/ mine hydrology, environmental geology, mineral resource waste, waste management, environmental regulations, and CERCLA' RCRA/EIS. Many schools have started to offer degrees in environmental science, environmental engineering, and various multi-disciplinary training programs designed around students' interests such as risk assessment and environmental regulation.

Montana Tech in Butte now offers an M.S. degree with an emphasis in mine and mineral waste technology. Selected courses offered include chemistry, environmental engineering, geology engineering, geophysics engineering, mining engineering, mechanical engineering oriented toward mine and mineral waste issues.

\subsubsection{Findings}

The universities and state and private schools seem to be satisfying training needs at present. However, there appears to be no encouragement for students to major in mine waste remediation or emphasize this in their curriculum.

Short courses focusing on cross fertilization of disciplines (science, engineering, legal, etc.) can help students and professional in need of continuing education develop a broader perspective.

If significant mine waste remediation is undertaken in the near future, the adequacy of the training programs will need to be reevaluated.

\subsection{DEMONSTRATION PROJECTS TO TEST SOLUTIONS}

At the request of the DOIT Committee, the Mine Waste Working Group sought to identify one or more projects that could be used to develop new approaches to mine waste technology deployment. Thirty three projects were reviewed at the Group's last meeting. Some of the projects were principally related to possible demonstration sites. Others involved methodologies associated with the remediation process. Still others were principally technology ori- 
ented. It was clear from the projects identified and the group's discussions that there are hundreds of projects that could be funded to test new remediation technologies and new approaches for remediating mining wastes. However, because of the Group's sense of the need to resolve other more pressing mine waste issues first, e.g., inventory, regulatory barriers, stakeholder issues, etc., the group chose not to recommend any of the proposed projects at this time. What follows is a description of the process used to identify potential projects and a description of some of those that seemed particularly linked to the issues and opportunities identified by the DOIT Committee and the Mine Waste Working Group.

\subsection{Process used to identify potential projects}

A representative subgroup of the Mine Group met and developed a questionnaire form to solicit information about issues and projects which might be of interest to the DOIT Committee (see Appendix B). The form was distributed to the entire Mine Waste Working Group with instructions to distribute it to anyone who ninght be interested. Thirty one projects were submitted by the time of the Group's subsequent meeting.

The Group struggled with the appropriate vehicle with which to identify projects and the linkage between that vehicle and the eventual funding of projects. Questions remain unanswered regarding whether a federal agency which chooses to fund a project would have to begin from ground zero with a request for proposals because of procurement requirements. These questions were muted to some degree by the direction in the revised DOIT Committee Management Plan. "Working groups will develop criteria to screen potential demonstration projects, technologies, and/or sites. The first step will be to screen existing projects/technologies/sites identified by federal agencies or private companies that are already set for demonstration." However, should the Committee request the Mine Waste Working Group's advice on projects not already in the funding pipeline, questions regarding solicitation and linkage to funding will need to be answered.

It should be noted that despite the Group's balanced and representative nature that, given the time constraints, the projects submitted do not represent the universe of possibilities for demonstration projects which might be appropriate for DOIT Committee consideration. It is hoped that they are representative and that a future effort could yield information useful to the Committee as well as commercializable technologies.

\subsection{How Projects were Evaluated}

The Group developed an evaluation sheet to review projects. However, after much debate it was determined that the projects crossed so many different issues that it was difficult to fairly rank the 
projects against one another based upon any numerical system of weighted measures. All of the projects which were submitted to the Group for review are contained in Appendix C. Also included in Appendix $\mathrm{C}$ are additional projects which were submitted after the last meeting and which have not been reviewed by the Group. All project descriptions are avallable upon request.

The Group used a nominal group process to subjectively match the projects against its criteria (see Appendix $D$ for criteria) in order to identify a set of several example projects which address different issues and present different opportunities. The table (Appendix E) summarizes nine promising projects. Some of the example projects are short term and some longer term. Some are fully funded; others have no funding associated with them as yet.

\subsection{CONCLUSION - NEXT STEPS}

Based upon the DOIT Committee's recommendations, and pending resolution of the Mine Waste Working Group's other recommendations, the Mine Waste Working Group is prepared to work with the sponsors of suitable projects to develop more complete workplans which will yield the important lessons for the DOIT Committee on how to improve the development, deployment, and eventual commercialization of innovative waste remediation technologies.

As part of project implementation, the Mine Waste Work Group is prepared to solicit information for projects that would be developed from the ground up. These projects will build on the lessons learned and will address technology needs for key cleanup concerns, test new regulatory and stakeholder approaches, and work to improve commercialization at mine waste sites. 
This page intentionally left blank. 


\section{APPENDICES}


Appendix A - Working Group List 


\section{Mine Waste Working Group - Official Members}

\author{
Steve Allred \\ Senior Vice President \\ Environmental Division \\ Morrison-Knudson Company \\ P.O. Box 7808 \\ Boise, ID 83729 \\ (208) 386-5000 \\ fax (208) 386-6198 \\ Brent Bailey \\ Noranda Minerals \\ $12 t-10$ W. Cedar Drive \\ Lakewood, CO 80228 \\ (303) 988-6456 \\ fax (303) $987-1298$ \\ Karen Barkley-Fagg \\ MSE, Inc. \\ P.O.Box 7225 \\ Billings, MT 59103 \\ (406) 255-7484 \\ fax (406) 255-7125 \\ Dave Bucknam \\ Colorado Dept. of Natural Resources \\ Division of Minerals and Geology \\ 1313 Sherman, Room 215 \\ Denver, CO 80203 \\ (303) 866-3567 \\ fax (303) 832-8106

\section{Phillip Cernera} \\ (rep. to Henry Sijohn) \\ Project Manager \\ NRDA Project Orïce \\ 424 Sherman Avenue, Suite 306 \\ Coeur d'Alene, ID 83814 \\ (208) 667-4119 \\ (208) 667-4657

\section{Dave Chambers} \\ Sierra Club Legal Defense Fund \\ 325 Fourth Street \\ Juneau, Alaska 99801 \\ (907) 586-2751 \\ fax (907) 463-5891 \\ Jack Duray \\ UNC Geotech \\ P.O. Box 1400 \\ Grand Junction, CO 81503 \\ (303) 248-6702 \\ fax (303) $248-6040$

\section{Tom Durkin} \\ Office of Minerals and Mining \\ South Dakota Department of \\ Environmental \& Natural \\ Resources \\ 523 East Capitol Avenue \\ Pierre, SD 57501 \\ (605) 773-4201 \\ fax (605) 773-6035

\section{Dr. Frederick J. Fraikor \\ Director Colorado Advanced \\ Materials Institute \\ Colorado School of Mines \\ Golden, CO 80401 \\ (303) 273-3606 \\ fax (303) 273-3656} \\ Michael Gregory \\ Arizona Toxics Information \\ P.O. Box 1896 \\ Bisbee, AZ 85603 \\ (602) 432-5324 \\ fax (602) 432-5324 \\ Robert L. Hanson \\ State Mining Coordinator \\ Division of Environmental \\ Quality \\ 1410 N. Hilton \\ Boise, ID 83720 \\ (208) 334-2100 \\ fax (208) 334-2175 \\ Jeff Heath \\ Environmental Programs \\ Naval Civil Engineering \\ Laboratory \\ 560 Laboratory Drive \\ Port Hueneme, CA 93043-4328 \\ (805) 982-1651
}


Dan Heilig

Wyoming Outdoor Council

201 Main Street

Lander, WY 82520

(307) 332-7031

fax (307) 332-7031

Jonathan Herrmann

Risk Reduction Engineering Lab 26 W Martin Luther King Dr.

Cincinnati, $\mathrm{OH} 45268$

(513) 569-7839

fax (513) 569-7787

\section{Bob Higgins}

Mining and Minerals Branch

National Park Service

P O. Box 25287

Denver, CO 80225

(303) 969-2092

fax (303) 969-2822

\section{Rick Humphreys}

Division of Water Quality

State Water Resources Control

Board

P.O. Box 944213

Sacramento, CA 94244-2130

(916) 657-0759

fax (916) 657-2388

\section{Bernie Hyde}

Bureau of Land Management (WO 750)

1849 C Street NW, MS 407LS

Washington, DC 20240

(202) 452-5057

fax (202) 452-5046

\section{James D. Jensen}

Montana Environmental Information

Center

P.O. Box 1184

Helena, MT 59624

(406) 443-2520
Roger Kennett

(rep. Loren Evans)

Arizona Dept. of Environmental

Quality

3033 North Central

Phoenix, AZ 80512

(602) 207-4179

fax (602) 207-4236

Thor Killsgaard

USGS - Retired

West 904 Riverside Ave, Room 117

Spokane, WA 99201-1087

(509) 353-2641

fax (509) 747-8980

\section{Carol Leach}

New Mexico Energy, Minerals and

National Resources Dept.

2040 S. Pacheco Street

Santa Fe, NM 87505

(505) 827-5940

fax (505) 438-3855

\section{Ann Maest}

RCG Hagler

18819 th St., Ste 201

Boulder, CO 80302

(303) 449-5515 X230

fax (303) 443-5684

\section{Roy Mink}

Idaho Water Resources Research Institute

Morrill Hall, Room 106

University of Idaho

Moscow, ID 83843

(208) 885-6429

fax (208) 885-6431 


\section{Richard Parks}

Northern Plains Resource Council

Western Orgnztn. of Resource

Councils

419 Stapleton Building

Billings, MT 59101

(406) 248-1154

fax (406) 252-1092

\section{Dick Perachini}

Colorado Department of Health

State Project Manager

4300 Cherry Creek Dr. South

Mail Code: HMWMD-RP-B2

Denver, CO 80222-1530

(303) 692-3396

fax (303) 759-5355

\section{Donna Pozzi}

Save Bodie! Committee of CSPRA

P.O. Box 292010

Sacramento, CA 95829-2010

(916) 653-4643

FAX (916) 447-5007

\section{Rick Richins}

Coeur d'Alene Mining Company

2417 Bank Drive, Suite 302

Bcise, ID 83705

(208) 385-0373

fax (208) 342-4365

\section{Paul Robinson}

Southwest Research \& Information

Center

P.O. Box 4524

Albuquerque, NM 87106

(505) 262-1862

fax (505) 262-1864

\section{Donna Rose}

Concerned Citizens of Triumph 90.33

544 Eastfork, Box 3730

Ketchum, ID 83340

(208) 788-9300

fax (208) 788-9337
Karen Scherger

332 S. Gilpin (home)

Denver, CO 80209

(303) 744-1008 (home \#)

\section{Bill Schmidt}

Bureau of Mines, Research

Environmental Technology

8107 th Street, NW, Mail 6205

Washington, DC 20241

(202) 501-9271 (9269)

fax (202) 501-9957

\section{Meade Stirland}

Echo Bay Mines

5401 Langley Lane Suite \#5

Reno, NV 89511

(702) 829-1000 ext 223

fax (702) 829-1067

\section{Terry Surles, Ph.D.}

Argonne National Laboratory

Building 372

9700 So Cass Avenue

Argonne, Il 60439-4832

(708) 252-3759

fax (708) $252-6407$

\section{Rob Walline}

Mine Waste Coordinator

EPA Region VIII

Denver Place Suite 500

999 19th Street

Denver, CO 80202-2466

(303) 294-7093

fax (303) 293-1424

\section{Sammy Winder}

National Tribal Environmental

Council

1225 Rio Grande North West

Albuquerque, NM 87104

(505) 242-2175

fax (505) 242-2654 
Doug Zimmerman

Mining Regulation and Reclamation

Div of Environmental Protection

333 West Nye Lane

Carson City, NV 89710

(702) 687-4675

fax (702) 687-5856

Alternates

\section{Robert Bartlett}

(alt to Roy Mink)

College of Mines and Earth Resources

University of Idaho

Moscow, ID 83843

(208) 885-6195

fax (208) 885-5724

\section{Dorland Edgar}

(alt to Terry Surles)

Argonne National Laboratory, Bld - 372

9700 So Cass Avenue

Argonne, Il 60439-4832

(708) $252-7596$

fax (708) 252-6407

\section{Dave Emilia}

(alt to Jack Duray)

P.O. Box 1400

Grand Junction, CO 81503

(303) 248-6417

fax (303) 248-6040

\section{Dennis Ferrigno}

(alt to Steve Allred)

7100 E. Belleview Ave., Suite 300

Englewood, CO 80111

(303) 793-5000

fax (303) 290-0238

James T. Firkins

(alt to Carol Leach)

NM EMNRD

2040 South Pacheco

Santa Fe, NM 87505

(505) 827-5950

fax (505) 438-3855

\section{Bim Gupta}

(alt to Terry Surles)

National Renewable Energy

Laboratory

1617 Cole Blvd.

Golden, CO 80401

(303) 231-1760

fax (303) 231-1155

\section{Mary Ann Harrington-}

Baker

(alt to Karen Barkley-Fagg)

MSE, Inc.

P.O. Box 3767

Butte, MT 59701

(406) 494-7240

fax (406) 494-7230

\section{Paul Jehn}

(alt to Roy Mink)

Univ. of Idaho/Boise Center 800 Park Bivd.

Boise ID 83712

(208) 334-2999

Orville Keane

(alt to Rob Walline)

EPA Region VIII

999 19th Street

Denver, CO 80202

(303) 294-7093

fax (303) 293-1424

Tom Leshendok

(alt to Bernie Hyde)

BLM Representative

P.O. Box 1200)(

Reno, NV 89520-0006

(702) 785-6576

fax (702) 785-6602

Anne M. Oberly

(alt to Rick Richins)

Coeur d'Alene Mining

Company

2417 Bank Drive, Suite 302

Boise, ID 83705

(208) 385-0373

fax (208) $342-4365$ 
Rob Robinson

(alt to Bernie Hyde)

Bureau of Land Management

2850 Youngfield

Lakewood, CO 80215

(303) 239-3642

fax (303) 239-3799

Observers \& Advisors

\section{Gary Broetzman}

Colorado Center for

Environmental Management

1746 Cole Blvd., Bldg. 21, Ste. 150

Golden, CO 80401

(303) 279-2700

fax (303) $279-9106$

\section{Glenn M. Eurick}

American Barrick Resources

Corporation

P.O. Box 838

Tooele, UT 84074

(801) 268-4447

fax (801) 266-4296

\section{George Hope}

Manager, Mineral Processing

LAC Minerals Ltd.

Royal Bank Plaza

21 st Floor, North Tower

P.O. Box 156

Toronto, Ontario M5J 2J4

\section{Mickey Lawler}

Eticam

2095 Newlands Dr.

Fernley, NV 8908

(702) $575-2760$

fax (702) 575

\section{Nancy Prindle}

Org. 6305

P.O. Box 5800

Sandia Nat. Labs

Albuquerque, NM 87185

(50) 848-0796

(505) 848-0789
Kim Reichart

Energetics, Inc.

7164 Columbia Gateway Drive

Columbia, MD 21046

(410) 290-0377

William Sharp

Colorado School of Mines

Golden, CO 80401

(303) 273-3762

fax (303 273-3244

\section{Mel Shupe}

Department of Energy

EM-54

1000 Independence Ave, SW

Washington, DC 20585

(301) 903-7942

fax (301) 903-7457

\section{Clinton Skinner}

Range Management

P.O.Box 3354

University Station

Laramie, WI 82071

(307) 766-4139

\section{Bob Starr}

EG\&G Idaho

P.O.Box 1625-2107

Idaho Falls, ID 83415

(208)526-5687

fax (208) 526-0875

\section{Steve Stein}

Integrated Demonstration

Coordinator

Battelle - PNL

4000 NE 41 st St.

Seattle, WA 98105-5428

(206) 528-3343

fax (206) 528-3552 
Staff

\section{Tim Brown}

(facilitator)

Clean Sites, Inc.

The Monadnock Building

53 West Jackson \#1632

Chicago, IL 60604

(312) 554-0900

fax (312) 554-0193

\section{Chris McKinnon}

Western Governors' Association

600 17th Street, Suite 1705 South Tower

Denver, Colorado 80202

(303) 623-9378

fax (303) 534-7309

Andrea Romano

Coleman Energy and

Environmental Systems

950 L'Enfant Plaza Center

Eighth Floor

Washington, DC 20024

(202) 863-0916

fax (202) 863-9259

Please note that the findings of the Mine Waste Working Group Report do not necessarily reflect the views of every member of the working group. Some members were not able to participate in the development of the report, nor were they able to fully review its contents. This report does not represent the official view' of any federal agency or department, state, or other group. 
Appendix B - Project Questionnaire Form 


\section{INSTRUCTIONS FOR COMPLETION OF THE MINE WASTE DEMONSTRATION PROJECT QUESTIONNAIRE FORM}

1. Please supply the name(s) and phone number(s) of the person(s) completing the questionnaire.

2. Please review the accompanying background information on the DOIT and Abandoned Mine Waste Working Group prior to completion of the questionnaire.

3. Please explain responses to questions, not give yes or no answers. Be through in your answers yet be as succinct as possible.

4. Remember that the questionnaire is for information gathering. The Mine Waste Working Group is an advisor to the DOIT Committee and has no ability to directly fund work or to solicit request for proposals.

5. The questionnaire must be returned by October 1,1993 to the following address:

Chris McKinnon

Western Governors' Association

60017 th Street, Suite 1705 South Tower

Denver, CO 80202-5452

(303) 623-9378

(303) 534-7309 fax 


\section{MINE WASTE DEMONSTRATION PROJECT QUESTIONNAIRE FORM}

\section{DOIT COMMITTEE MINE WASTE WORKING GROUP MINE WASTE DEMONSTRATION PROJECT QUESTIONNAIRE FORM - 9/17/93}

\section{BACKGROUND INFORMATION}

Please provide project name, site location, location of demonstration project on the site, Project Demonstration Team, state agency, and/or Federal organizations involved in demonstration.

\section{SITE CHARACTERISTICS}

Please provide site geology/media, climate conditions, population density, proximity to major population center, type of mine, surface and groundwater, site access, representativeness of problems at other sites, available utilities, and infrastructure.

Describe nature and source of contamination (e.g. organics, metals, etc.) volume, area, principle regulatory drivers, human health impacts, ecological impacts, etc.

\section{DEMONSTRATION TECHNOLOGY CHARACTERISTICS}

Describe type of demonstration technology, stage of development (technology maturity), scale, project time frame, schedule flexibility, indicators, and methods of measuring success, key project milestones, contingent technologies, applicable to other sites, pollution prevention, resource recovery. Is the technology characterized as a source control or pollution control (ie. treating the symptom)? How is this technology better than conventional technologies? Does technology enhance beneficial land use over conventional technologies?

\section{LEVEL OF INTEREST}

Does Project Demonstration Team understand the DOIT process and mission?

Are responsible parties/decisionmakers generally interested in partnering with the DOIT?

What leveNypes of information are project proposers willing to share with DOIT?

Is there interest in working with DOIT to improve commercialization potential?

Is there interest in working with DOIT to improve stakeholder involvement?

Is there interest in working with DOIT to improve regulatory acceptance?

\section{RESOURCE AVAILABILITY}

Are resources available to support/interface with the DOIT process?

(Management experience, technical expertise, equipment, labor, etc.)

\section{REGULATOR RELATIONS}

What are the key regulatory processes involved with the demo (applicable Federal, State, and local laws and regulations)?

How are regulators involved and to what degree? 


\section{MINE WASTE DEMONSTRATION PROJECT QUESTIONNAIRE FORM}

\section{STAKEHOLDER RELATIONS}

Who are the key stakeholders involved with the demo (citizen groups, environmental groups, local communities, responsible parties if any, past and current operators, land owners and managers, etc.)?

What is nature of stakeholder participation in the demo?

How are stakeholders involved in the demonstration project?

\section{ECONOMIC/COMMERCIALIZATION POTENTIAL}

What is the experience of the proposed project team in implementing and commercializing innovative technologies (provide specific examples)?

Are there any proprietary considerations that may impede technology transfer/commercialization?

If possible, provide your impressions as to the commercialization potential for the technology?

\section{KEY BENEFITS TO DOIT PROCESS}

Provide an assessment of national benefits (e.g., commercialization potential, application to other sites) to be gained by the workgroup and DOIT participation in the demonstration.

\section{FUNDING}

Describe funding history, available funding, additional funding required for your technology demonstration project. (Is there funding for future?)

11. POTENTIAL BARRIERS TO SUCCESS AND/OR CONDITIONS FOR DOIT INVOLVEMENT Identify potential barriers (including regulatory and institutional) to initiating and/or completing proposed technology demonstration. Please explain (level of liability, litigation, stakeholder disagreement, etc.) How may these barriers be addressed?

\section{KEY CONTACTS}

Provide a list of key contacts, (regulators, contractors, other stakeholder group representatives, etc) their organizational affiliation and phone numbers.

Please mail or fax the answers to these questions to Chris McKinnon, Western Governors' Association, 600 17th Street, Suite 1705 South Tower, Denver, CO 80202-5452, (303) 623-9378, FAX (303) 534-7309 by October 1, 1993. 


\title{
MINE WASTE DEMONSTRATION PROJECT QUESTIONNAIRE FORM
}

\author{
Evaluation Scoresheet
}

1. Check the type(s) of thrust(s) the proposal is targeted toward and evaluate accordinly in the chart below:

Site

Technology

Institutional/regulatory/other proposal

2. What is the timeframe for achieving objectives of the proposal:
1 year
$2-5$ years
5-10 year
N/A

\begin{tabular}{|c|c|c|c|c|}
\hline & + & - & Unclear & $\begin{array}{c}\text { Not } \\
\text { applicable }\end{array}$ \\
\hline \multicolumn{5}{|l|}{ Representativeness of problems at other sites (S) } \\
\hline \multicolumn{5}{|l|}{ Required utilities, infrastructure, and access available (S) } \\
\hline \multicolumn{5}{|l|}{ Schedule flexibility (S) } \\
\hline \multicolumn{5}{|l|}{ Commercialization potential $(\mathrm{T})$} \\
\hline \multicolumn{5}{|l|}{ Potential applicability of technology to other sites (T) } \\
\hline \multicolumn{5}{|l|}{ Technology supports pollution prevention $(T)$} \\
\hline \multicolumn{5}{|l|}{ Technology supports resource recovery $(\mathrm{T})$} \\
\hline \multicolumn{5}{|l|}{ Cost-savings over alternative methods (T) } \\
\hline \multicolumn{5}{|l|}{ Level of technology maturity (T) } \\
\hline \multicolumn{5}{|l|}{ Potential for success of environmental remediation $(\mathrm{S}, \mathrm{T})$} \\
\hline \multicolumn{5}{|l|}{ Level of regulator involvement $(\mathbf{I}, \mathbf{S})$} \\
\hline \multicolumn{5}{|c|}{ Potential for overcoming regulatory and institutional barriers (I) } \\
\hline \multicolumn{5}{|c|}{ Project Demonstration Team's understanding of DOIT (I,S,T) } \\
\hline \multicolumn{5}{|l|}{ Level of stakeholder involvement $(\mathrm{I}, \mathrm{S}, \mathrm{T})$} \\
\hline Potential for success is effectively monitored $(\mathrm{I}, \mathrm{S}, \mathrm{T})$ & & & & \\
\hline
\end{tabular}

OVERALL COMMENTS:

r\&dmine.frm

Page 4 of 4 
Appendix C - Mine Waste Projects 


\section{Mine Waste Projects \\ Submitted as of October 5, 1993}

Midnite Mine (Washington)

Bill Schmidt, USBM, 202-501-9271

Project to develop an improved basis for stakeholder involvement

Midnite Mine (Washington)

Bill Schmidt, USBM, 202-501-9271

Project to study treatment of contaminated waters, both high volume for near term and low volume treatment for longer term

Mine Waste Technology Pilot Program - In Situ Control of Acid Generation by the use of Sulfate Reducing Bacteria - Lilly-Orphan Boy Mine (Montana)

Thomas F. McIntyre, MSE Inc., 406-494-7435

Project to result in inhibition of natural occurring acid generation

Integrated Characterization and Remediation of the Triumph Mine (Idaho)

Dr. Robert C. Start, INEL, 208-526-5687

Project to address water draining from the mine portal, sludges near the mine portal, contaminated soil near ore process plant, tailings piles, ground water, ephemeral stream in upper tailings pile, and soil in residential areas

Prescott Mining Project - Sheldon Mine (A rizona)

Andy Cajero - Travers, ADEQ - Project Lead, 602-207-4468

Project to deal primarily with tailings and waste rock dumps

Nelson Tunnel (Colorado)

Rob Robinson, BLM, 303-239-3642

Project to demonstrate passive water treatment of acid mine drainage, sealing of mine wastes, and mine closures

Coeur d'Alene Basin Restoration Project (Idaho)

Geoff Harvey, IDEQ, 208-769-1448

Project to reclaim mine adit drainages rich in heavy metals and located in steep, narrow canyons

Blackbird Mine (Idaho)

Dr. Robert W. Bartlett, University of Idaho, 208-885-6195

Project to remediate acid mine heavy metal drainage, mine tailings, and mine waste rock dumps

Pennsylvania Mine (Colorado)

Bruce Store, Colorado Division of Minerals and Geology, 303-866-3567 
Project to demonstrate semi-passive mine drainage acid neutralization/metals precipitation system to improve water quality

Sharon SteelMidvale Taillings Superfund (Utah)

Carol Wager Pfarr, UDEQ, 801-536-4100

Project to reprocess mine waste tailings

Mine Waste Technology Pilot Program - Blological Destruction of Cyanide Demonstration (Western State)

Dr. Martin Foote, MSE Inc., 406-494-7431

Project to develop a system to treat aqueous mine waste contaminated with cyanide

Inventory of Abandoned Non-Coal Mines (N/A)

Bill Schmidt, USBM, 202-501-9271

Project to develop a valid inventory of abandoned non-coal mines

5-M Silver Reef Site (Utah)

Rob Robinson, BLM, 303-239-3642

Project to remediate a defunct ore processing facility that used an acid heap leach projects for the extraction of copper and silver

Mine Waste Technology Pilot Program - Remote Site Acid Water Demonstration (Montana)

Dr. Martin Foote, MSE Inc., 406-494-7431

Project to develop a system to treat the acidic, metal-laden water by the use of alkaline reagents

Leeds Silver Site (Utah)

Dennis T. Trexler, University of Nevada, 702-784-6151

See above

Relief Canyon Mine - Blosolids Mine Land Reclamation (Nevada)

Dennis T. Trexler, University of Nevada, 702-784-6151

Project to use biosolids for mined land reclamation in the West

Spenceville Mine Abatement Project (California)

James S. Pompy, CA Dept. of Conservation Division of Mines and Geology, 916-323-8565

Project to provide abatement of acid sources of ore dumps, waste dumps, tailings and the wall rock in the mine pit

Humbolt River Drainage (Nevada)

Christopher D. Henry, University of Nevada, 702-684-6691

Project to assemble existing information about the geologic-hydrologic-geochemical setting of abandoned mines in a GIS data base

Resource Recovery Project - Berkeley PIt (Montana) 
DOE In Situ Remediation Integrated Program - Hanford Underground Storage Tank Integrated Demonstration

Jeffrey Walker, DOE/EM-541, (301) 903-7966

Containment of Contaminants through Physical Barriers Formed from Viscous Liquids

Emplaced under Controlled Viscosity Conditions

DOE In Situ Remediation Integrated Program - Fernald Site, Ohio

Jeffrey Walker, DOE/EM-541, (301) 903-7966

Surface Controlled Emplacement of Horizontal Barriers Beneath Waste Sites

DOE In Situ Remediation Integrated Program - Site Undetermined

Jeffrey Walker, DOE/EM-541, (301) 903-7966

Hydraulic and Diffusion Barriers in the Vadose Zone Surrounding Buried Waste

DOE In Situ Remedintion Integrated Program - SEG, Inc.'s facility in Oak Ridge, TN

Jeffrey Walker, DOE/EM-541, (301) 903-7966

Soil Freezing Technology Applications

DOE In Situ Remediation Integrated Program - Site Undetermined

Jeffrey Walker, DCE/EM-541, (301) 903-7966

Chemically Enhanced Barriers to Minimize Contaminant Migration

Mine Waste Projects Submitted After October 5, 1993

Southwest New Mexico Mine Waste Demonstration Project .. New Mexico

Nancy Prindle, Sandia National Laboratory, 505-848-0798

Project to demonstrate commercial applications of characterization, containment, extraction, and assessment technologies for metals, acids and other hazardous wastes

Phelps Dodge Site -- New Mexico

David A. Emilia. RUST Geotech. Inc., 303-248-6417

See Above

In Situ Permeable Flow Sensor .. New Mexico

Sanford Ballard, Sandia National Laboratory, 505-844-6293

Project to measure groundwater flow velocity

National Molten Salt Oxidation Program .. Colorado, Califomia

Lawnie H. Taylor, DOE/EM-43, 301-903-8119

Project to control pollution that: eliminates the afterburner; does not form dioxins; destroys

acids; and confines final waste form for recycling

Laser Induced Fluorescence Imaging .- Site Undetermined

Caroline Purdy, DOE, 301-903-7672

Project to scan the field of view to receive an image of the materials that fluoresce with laser light and display the image on a screen similar to a TV or computer screen 
Appendix D - Project Criteria 


\section{Project Criteria}

The Mine Waste Working Group has reviewed and revised the draft project criteria proposed by the Ad Hoc General Criteria Group. Our proposed criteria are as follows.

PREAMBLE: These criteria are applicable to either test bed or site specific projects.

\section{General Acceptance Criteria for Projects and Proposals}

1. Federal interest site preferably in the West: Very Important

2. Stakeholders are identified and involved in the proposed design, testing, and evaluation of the project, through a strong and balanced team: Very Important

3. Proposed project will address the manner in which innovative technologies are developed, selected, deployed, tested, evaluated, and/or commercialized: Important

4. Project will field test new promising innovative technology or innovative applications of existing technology: Very Important

5.The proposal clearly states environmental restoration or waste management problem and states how the proposed technology addresses the problem: Very Important

6. Special consideration will be given to projects which include private sector funding and management support and involve partnerships that promote commercialization: Important

7. Project is feasible given available funding: Important

8. The proposal should assure that project decision making includes equal access by the diverse cultural and economic groups potentially affected by the proposed activity: Very Important

9. The project should offer the potential to improve the legal/regulatory process for mine waste technology development and cleanup: No ranking

10. The project should offer the potential to enhance the ecosystem and the environment: No ranking

\section{Site Selection Criteria}

1. Proposed demonstration site is supported by stakeholders: Very Important

2. Site is representative of critical site problems at government and other sites. Very Important

3. Significant levels and overall volume of contamination are present to both challenge the technology and to facilitate a statistical evaluation of the effectiveness of the technology: Very Important 
4. There is an ability of the demonstration site to account for site-to-

site variabilities and establish the range of effectiveness and cost for a technology: Important -Very Important

5.The required utilities and infrastructure (both human and physical) are available: Less Important

\section{Technology Selection Criteria}

1.The technology is potentially better, faster, or safer compared to conventional and baseline technology. Very Important

2. The technology has expected outcomes that are measurable and clearly understood: Very Important

3. Proposed demonstration technology is supported by stakeholders: Very Important

4. The technology has the potential for resource recovery. Very Important

5. The technology has the potential for pollution prevention. Very Important

6. The technology has the potential to be applied to waste generation at active mines. Important

\section{Performance Evaluation Criteria}

\section{Technical:}

1. Did the technology achieve established test objectives? Important

2. Did the demonstration project contribute to a better understanding of the usefulness of the technology? (Mini sites for demonstration within larger fonnally designated areas should be considered.) Very Important

3. Are demonstrations broadly applicable to other sites? Important

4. Were the test protocols adequate? Very Important

\section{Process:}

1. Did the demonstration contribute to the resolution of commercialization issues for the technology? Very Important

2. Were stakeholders appropriately involved? Did or could they play a significant role in light of the technical and other complex issues, such as regulatory issues, involving the application of innovative technology? Was the outcome acceptable to stakeholders? Did the project sponsors understand and address adequately the stakeholder concerns? Very Important 
3. Did the demonstration contribute to the improvement of the process of technology development and deployment: Very Important

4. Did the demonstration provide adequate information for user adoption or adaptation? Very Important

5. Was the demonstration completed on time and within budget? Very Important

6. Did the demonstration show natural resource enhancement and/or recovery? Very Important

7. Were regulatory or other impediments encountered and, if so, were they addressed? Very Important 


\section{Appendix E - Potential Mine Waste Candidate Demonstration Projects}


EXAMPLES OF POTENTIAL MINE WASTE CANDIDATE DEMONSTRATION PROSECTS FOR DOIT COMIITIEE CONSIDERATION (10/18/93)

\begin{tabular}{|c|c|c|c|c|}
\hline SITE & SPONSORS & ISSUE & FUNDING & OPPORTUNITIES \\
\hline Midnite Mine (WA) & U.S. Bureau Mines & $\begin{array}{l}\text { open technology "test off" for remedy } \\
\text { selection (water contamination) }\end{array}$ & FY 94 funding available (DOI) & $\begin{array}{l}\text { - Develop/test tribal stakeholder } \\
\text { involvement } \\
\text { stakeholder involvement in tech } \\
\text { selection } \\
\text {. liability waiver evaluation }\end{array}$ \\
\hline $\begin{array}{l}\text { Lilly-Orphan Boy Mine } \\
\text { (MT) }\end{array}$ & EPA/DOE (MWTPP)/MT & $\begin{array}{l}\text { innovative technology demonstration } \\
\text { (bacteria for metals mine drainage) }\end{array}$ & funded for FY 94 (EPA) & $\begin{array}{l}\text {-multi-state tech. review/market } \\
\text { ident if ication possible }\end{array}$ \\
\hline Triumph Mine (ID) & DOE (INEL)/Univ of $10 / 10$ & $\begin{array}{l}\text { integrated site characterization for cost } \\
\text { effective remedy selection (metals } \\
\text { contamination of air. soil. water) }\end{array}$ & no funding & $\begin{array}{l}\text { - evaluate Superfund list ing } \\
\text { - stakeholder involvement in } \\
\text { characterizat ion/remedy } \\
\text { select ion }\end{array}$ \\
\hline $\begin{array}{l}\text { Pennsylvania Mine } \\
\text { (CO) }\end{array}$ & CO/EPA/univ/volunteers & $\begin{array}{l}\text { low-cost innovative technology } \\
\text { (acid drainage at high alpine. } \\
\text { inaccessible site) }\end{array}$ & $\begin{array}{l}\text { funding for FY } 94 \text { pending } \\
\text { (EPA - CWA } 319 \text { ) }\end{array}$ & $\begin{array}{l}\text { stakeholder support / invalvement } \\
\text { liability waiver evaluat ion } \\
\text { possible } \\
\text { mult } i \text {-state tech review/market } \\
\text { ident ification possible }\end{array}$ \\
\hline site undetermined & EPA/DOE (MWTPP) & $\begin{array}{l}\text { innovative tech. demo } \\
\text { (cyanide contamination of water) }\end{array}$ & funded for FY 94 (EPA/DOE) & $\begin{array}{l}\text { - stakeholder involvement in site } \\
\text { select ion/tech. review } \\
\text { miti-state tech review/market } \\
\text { ident if icat ion possible } \\
\text {-tech transfer }\end{array}$ \\
\hline Sheldon Mine (AZ) & AZ/Forest Serv /ASARCO & $\begin{array}{l}\text { evaluate long term results of tailings } \\
\text { reclamation }\end{array}$ & $\begin{array}{l}\text { partially funded } \\
\text { Fy } 94 / \text { additional funds needed }\end{array}$ & $\begin{array}{l}\text {-multi-state tech review/tech } \\
\text { transfer }\end{array}$ \\
\hline Nelson Tunnel $(\mathrm{CO})$ & $\mathrm{BLM} / \mathrm{CO} / \mathrm{USGS} /$ USBOM/Univ & $\begin{array}{l}\text { low cost innovative tech. demo/remediation } \\
\text { (acid drainage. sealing. closure) }\end{array}$ & $\begin{array}{l}\text { in-kind staff \& travel } \\
\text { donated/funding needed for } \\
\text { construct ion \& peer review }\end{array}$ & $\begin{array}{l}\text { - stakeholder involvement in how } \\
\text { clean is clean enough arid at } \\
\text { what cost } \\
\text { - multi-agency cooperat ion' } \\
\text {-mult i state tech review/market }\end{array}$ \\
\hline $\begin{array}{l}\text { Coeur d'Alene Basin } \\
\text { (ID) }\end{array}$ & 10/EPA/tribe & $\begin{array}{l}\text { innovat ive technology matching to site } \\
\text { problem \& demo (drainage in steep canyon) }\end{array}$ & $\begin{array}{l}\text { funding needed for tech } \\
\text { review } \& \text { demo }\end{array}$ & 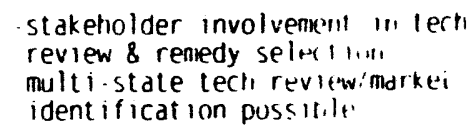 \\
\hline BlackDird Mine (ID) & $\begin{array}{l}\text { Univ of ID/Water Resources } \\
\text { Research Inst }\end{array}$ & $\begin{array}{l}\text { univ developed innovative tech } \\
\text { demonstrat ion/basin restoration (acid } \\
\text { drainage. sealing. closure) }\end{array}$ & $\begin{array}{l}\text { \$5. } \$ 10 \text { million needed over } \\
\text { five years }\end{array}$ & $\begin{array}{l}\text { multi-state tech, review/market } \\
\text { identification pu, ill. }\end{array}$ \\
\hline
\end{tabular}

f iflestrodmine or l 

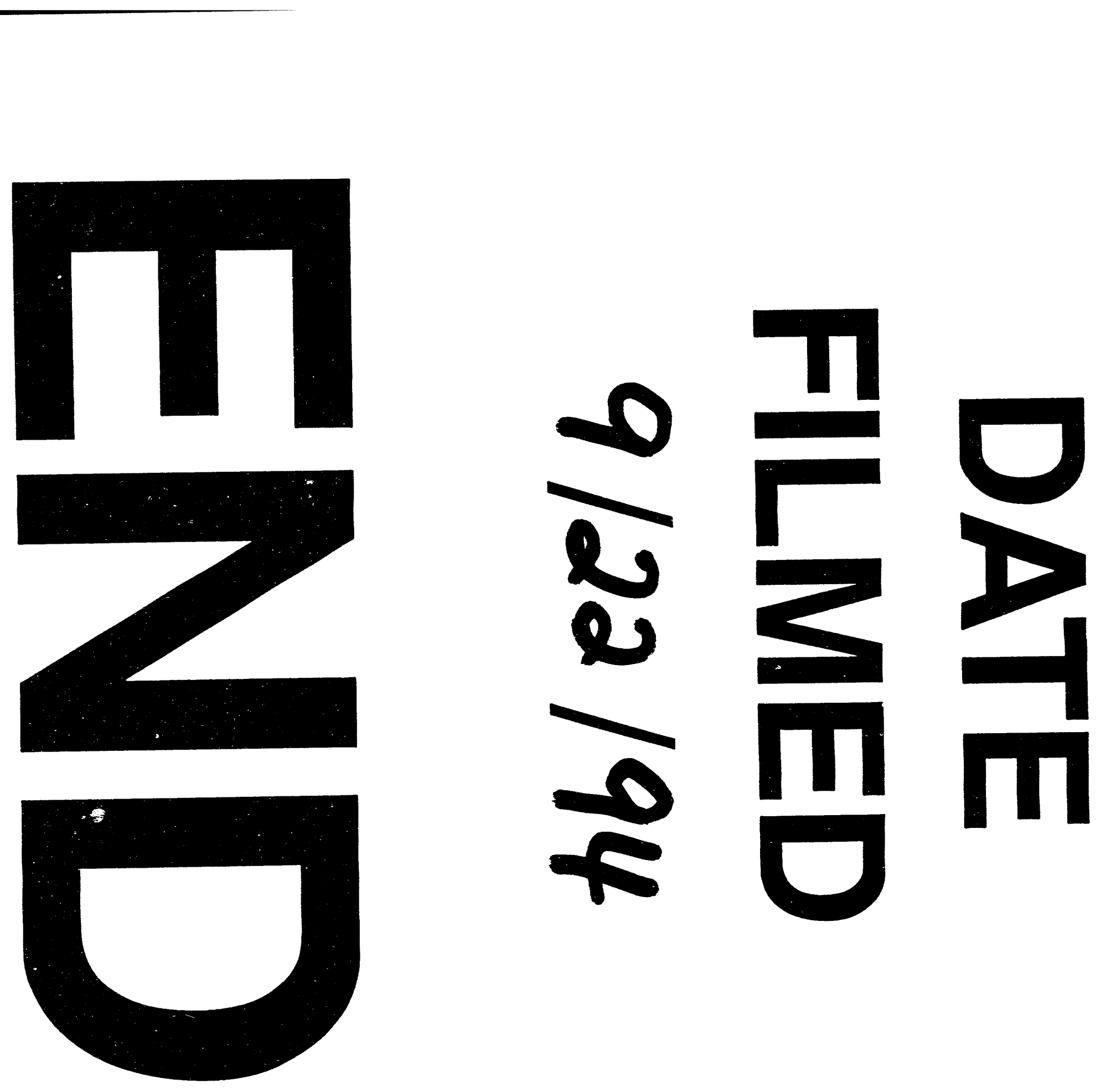


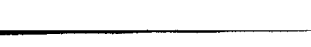

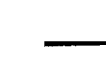
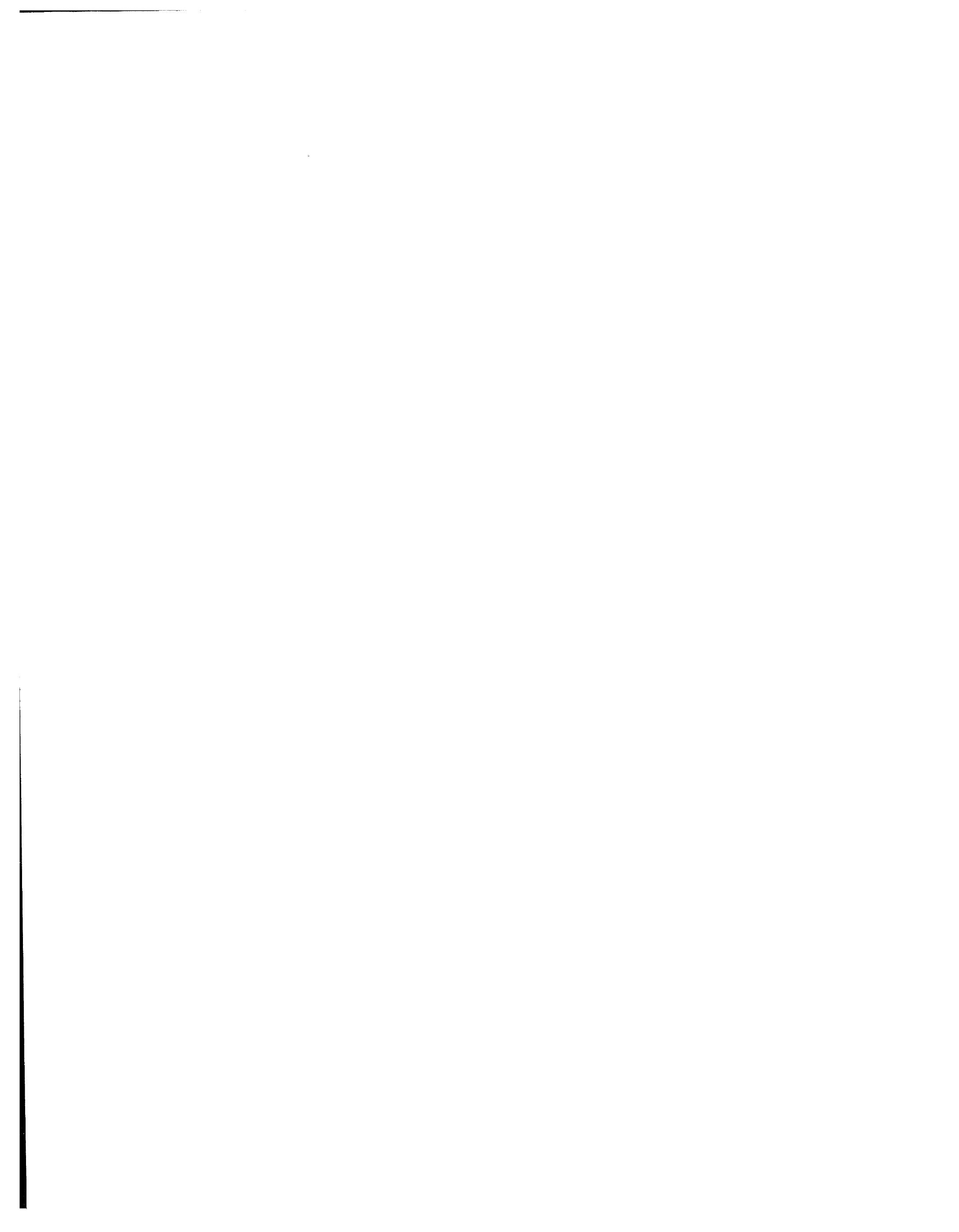